\title{
An Intellectual Stuck Between Theory and Social Practice: Gökalp and Culture-Civilization Theory
}

\author{
Yücel Bulut ${ }^{1}$ \\ İstanbul University
}

\begin{abstract}
This article examines Gökalp's approach to culture-civilization. Gökalp's theory of culture-civilization is generally widely accepted and handled as an approach that presents the formula of how Turks and Muslims can Westernize while at the same time preserving their identities. This study will attempt to draw attention to another feature of this theory. The basic claim of this essay is that Gökalp's culture-civilization theory, which claims to solve the mental problems Turks experience as a state and society on the topic of Westernization, at the same time embodies many potential problems on the points of thought and praxis. These problems stem from the concepts of culture and civilization weightily conflicting with each other, especially from the contradictory notion that the concept of "Turkish-ness" contains. This article tries to demonstrate these problematic areas by primarily dealing with the etymological developments of the concepts of culture and civilization. Afterwards, Gökalp's general understanding of society, approaches related to Turkish society, and specifically the theory of culture-civilization theory are analyzed. Lastly, what Gökalp's concepts and theory contain is subjected to a critical analysis to show its contradictory aspects.
\end{abstract}

$$
\begin{gathered}
\text { Keywords } \\
\text { Ziya Gökalp } • \text { Emile Durkheim } \bullet \text { Turkish sociology } \bullet \text { Culture } \bullet \text { Civilization }
\end{gathered}
$$

\section{Sosyal ve Siyasal Arasına Sıkışmış Bir Düşünür: Ziya Gökalp ve Hars-Medeniyet Kuramı}

$$
\ddot{\mathrm{O} z}
$$

Bu yazıda, Gökalp'in 'hars-medeniyet' yaklaşımı irdelenmektedir. Gökalp’in hars-medeniyet kuramı, yaygın olarak, Türk ve Müslüman kimliğimizi korumayı başararak nasıl Batılılaşabileceğimizin formülünü sunan bir yaklaşım olarak kabul görmüş ve işlenmiştir. Bu çalışmada ise, söz konusu kuramın bir başka özelliğine dikkat çekilmeye çalışılacaktır. Bu yazının temel iddiası; batılılaşma konusunda devlet ve toplum olarak yaşadığımız zihniyet problemlerini çözme iddiası taşıyan hars-medeniyet kuramının, aynı zamanda, düşünce ve uygulama noktasında pek çok potansiyel sorunu bünyesinde barındırdığıdır. Söz konusu sorunlar; kültür ve medeniyet kavramlarının birbirlerine karşıt anlamlarla yüklü kavramlar olarak kavranmasından ve özellikle de 'Türklük' kavramının içerdiği çelişik kavramlaştırmalardan kaynaklanmaktadır. Bu makalede, söz konusu sorun alanları öncelikle hars (kültür) ve medeniyet kavramlarının etimolojik gelişimi ele alınarak gösterilmeye çalışlıyor. Ardından Gökalp'in genel toplum anlayışı, Türk toplumuna ilişkin yaklaşımları ve özelde de 'hars-medeniyet' kuramı değerlendiriliyor. Son olarak da, Gökalp’in kavramlarının ve kuramının içeriğin, çelişik yönlerini gösterecek şekilde eleştirel bir değerlendirmeye tabi tutuluyor.

\author{
Anahtar Kelimeler \\ Ziya Gökalp • Emile Durkheim • Türk Sosyolojisi • Kültür • Medeniyet
}

\footnotetext{
* Correspondence To: Yücel Bulut (Prof), Department of Sociology, İstanbul University, Beyazıt, Fatih İstanbul. Email: yucel.bulut@istanbul.edu.tr

Citation: Bulut, Y. (2016). An intellectual stuck between theory and social practice: Gökalp and culture-civilization theory. Turkish Journal of Sociology, 36, 551-573.
} 
This study is an attempt to understand Gökalp's perception, definitions, interpretation, and utilization of the concepts of "culture" and "civilization." The objective of this paper is to show that Gökalp assigned different meanings to these concepts and used them to symbolize two opposing worlds. Thus the paper will also discuss his intention in separating these concepts into three sections. First, I will focus on etymology and the different uses of these concepts. The purpose here is to reflect the content and contextual transformation of these concepts throughout different periods, countries, and traditions under specific intentions. Second, I will discuss Gökalp's understanding, definition, and use of these concepts while also taking into account the striking changes observable in his articles over time in terms of his use and definition of these concepts. Third, I will analyze some vague and even contradictory points in Gökalp's culture-civilization theory by providing certain justifications. In this attempt, it is important to understand and identify the intellectual traditions that inspired and fostered Gökalp's use of these concepts. In addition, it will also contribute to the study to include how Gökalp's followers and critics perceived, interpreted, and utilized these concepts.

\section{Culture and Civilization: A Brief Etymological and Sociological History}

The dictionary defines "culture" in association with the "cultivation of the land" (in: English ${ }^{1}$ and French, culture; German, Kultur; Arabic, sakafi; Persian, ferhengi; Ottoman, hars; and Turkish, ekin or kültür). However, it has been used in the field of humanities ever since anthropologist Edward B. Tylor described it in the first paragraph of his book Primitive Culture as "Culture or civilization, taken in its wide ethnographic sense, is that complex whole which includes knowledge, belief, art, morals, law, customs, and any other capabilities and habits acquired by man as a member of society," (Tylor, 1871, p. 1). Tylor further developed this definition in Anthropology (1881), which has been in use for a long while. Developments in anthropology and additional research have made the concept very rich and complex. ${ }^{2}$

1 Raymond Williams explains the meanings the word received after the Age of Enlightenment. According to Williams, "the first word is cultura, (Latin), from the root colere-. Colere had a range of meanings: inhabit, cultivate, protect, honour with worship. Some of these meanings eventually were lost, though still with occasional overlap in its derived nouns. Thus the meaning of inhabit developed from colonus (Latin) to colony. Honor with worship developed through cultus (Latin) to cult. Cultura took on the main meaning of cultivation or tending, as included in Cicero, cultura animi, though with subsidiary medieval meanings of honor and worship... The French forms of cultura were couture, of, which has since developed its own specialized meaning, and later culture, which by the early $15^{\text {th }}$ century had passed into English. The primary meaning was then in husbandry and the tending of natural growth. Culture in all its uses was a noun process: the tending of something, basically crops or animals. The subsidiary coulter (ploughshare) had travelled a different linguistic route from culter (Latin) ploughshare, culture (Old English) to the variant English spellings culter, colter, coulter, and as late as the early $17^{\text {th }}$ century, culture." (Williams, 1985, p. 87).

2 "During this process [i.e., including the word "culture" into anthropology] the concept of "culture" has been stripped of some ethnocentric connotations and adapted to the requirements of ethnographic depiction. Cultural studies are now less concerned about the glorification of mind and soul in the heart of Europe and more concerned about enlightening the customs, practices, and beliefs of societies other than Europe." (Thompson, 2013, p. 152). 
Koreber and Kluckhohn (1963) gave 164 different definitions of culture in their work, Culture: A Critical Review of Concepts and Definitions. Since then, the content and concept of culture have continuously expanded, becoming more complex as various disciplines also adopt the concept.

As described by Thomas (2012, p. 176) in the social sciences, culture "is a term used instead of community" as "... a concept that defines the symbolic world experienced when one becomes a member of a social group." Thomas' use of this concept is consistent with how the word resonates in German. Raymond Williams summarizes the word's change in meaning as:

...borrowed from French, spelled first [1 $8^{\text {th }}$ century] Cultur and from [19 ${ }^{\text {th }}$ century $]$ Kultur. Its main use was still as a synonym for civilization: first in the abstract sense of a general process of becoming civilized or cultivated, and second in the sense which had already been established for civilization by the historians of the Enlightenment and in the popular $18^{\text {th }}$-century form of universal historians as a description of the secular process of human development. (Williams, 1985, p. 89)

By the early 19th century the word culture was being used as a synonym for, or in some cases in contrast with, the word civilization. Derived from the Latin word civic, which means of or belonging to citizens, civilization was initially used in French and English in the late 18 th century to describe a progressive process of human development, a movement towards refinement and order and away from barbarism and savagery. Behind this emergent sense lay the spirit of the European Enlightenment and its confident belief in the progressive character of the modern era.

In French and English, the uses of the words "culture" and "civilization" overlapped: both were used increasingly to describe a general process of human development, of becoming "cultivated" or "civilized." In German, however, these words were often contrasted in such a way that Zivilisation acquired a negative connotation and Kultur a positive one. Zivilisation was associated with politeness and the refinement of manners, while Kultur was used more to refer to the intellectual, artistic, and spiritual products in which the individuality and creativity of a community were expressed (Thompson, 2013, pp. 149-150).

The opposition of Kultur and Zivilisation in German was associated with early modern social stratification patterns in Europe. This relationship is analyzed in detail by Elias in the work Civilizing Process (2002/1939). Elias indicated in his study that the language of aristocracy and the upper layers of the bourgeoisie of 18th century Germany were French. Speaking French and imitating and following the traditions of the French royalty were status symbols for the upper class. Apart from the upper class, there were a small group of German-speaking intellectuals, mostly palace officers and land nobles. For these intellectuals, intellectual and artistic achievements were valuable; therefore, they ridiculed the upper class who spent all their energy becoming more polite, more refined, and more French. The upper class expressed this controversy through the opposition of Kultur and Zivilisation, defining their status through the concept of Kultur. 
The German historian Herder significantly changed the meaning of the word culture. Herder thought the concept was very ambiguous and deceptive when applied to all nations and eras, stating that every historical period or civilization possessed a unique character of its own. He opposed the thesis that each civilization is the forerunner of the next "higher" one, and thus the supremacy of Eurocentric culture over the rest of the world. It is not possible to work with linear conceptualizations of historical change and progress alongside comparisons of different peoples. Herder substantiates the diversity and incommensurability of civilizations at every level of human life, but it does not lead to the idea of assigning essentialist characteristics to specific peoples or historical periods. Herder insists that there is no single standard of culture. The difference between enlightened and unenlightened, or cultured and uncultured, peoples is relative and a matter of degree. Only a plurality of cultures, each realizing a unique balance of contradictory needs, can bring wholeness to the commonness of human nature. ${ }^{3}$

This sense of culture was widely developed in the Romantic Movement as an alternative to the orthodox and dominant "civilization." From this, the new concept of folk-culture emerged, emphasizing national and traditional cultures. This sense of culture was primarily a response to the emergence of the mechanical character of the new civilization, and was used to distinguish between human and material development (like the distinction between culture and civilization). These two concepts started to be used to indicate the distinction between rural and urban lifestyles, which were known to represent two distinct values, faiths, or even gods. "From the Industrial Revolution to the beginning of the $19^{\text {th }}$ century, modern civilization was first linked to extraordinary increases in population and urbanization, and consequently resolving traditional order through the mind," (Adorno \& Horkheimer, 2011, p. 105). Adorno and Horkheimer's account of the historical change in the meaning of these two concepts draws attention to this aspect:

In German orientalism, especially after Müller, in 19th-century Russian culture philosophy, culture was associated with country and civilization with city... Culture, which means

3 "The concept of culture that emerged in the late 18th and early 19th centuries as the classical conception of culture was mentioned in the histories of the development of humankind. This classical conception was also articulated by German historians and philosophers like Adelung, Herder, Meiners, and Jenisch. The 'history of culture' first emerged in Adelung's work, dated 1782. During these years, culture was defined as the process of developing and ennobling the human faculties, a process facilitated by the assimilation of works of scholarship and art, and linked to the progressive character of the modern era. The most well know of these early histories of culture was Ideen zur Philosophie der Geschichte der Menschheit by J. G. von Herder which was first published in 1784 and 1791 in four volumes. In this extensive study, although he preserves some of the emphasis of his contemporaries, Herder employs a critical approach to ethnocentrisms... Herder says, 'It had never entered into my mind by exploring the few figurative expressions, the childhood, infancy, manhood and old age of our species the chain of which was applied for a few nations. Is there a community on earth that is entirely exempt from culture? If each individual of the human species is to be shaped by culture, refined weakness would be a more appropriate term for it. Nothing could be more vague than the term itself; nothing else would lead us more astray than applying culture to all nations and ages."' (Thompson, 2013, pp. 150-151). 
living together ethically, has been in controversy with civilization as a hedonistic selfabasement since ancient times as could be seen in poetry. (p. 106)

In this context, Wagner and Tönnies had extreme reactions to civilization (alongside modernization, urbanization, and capitalism) within the context of populist-communal and even socialist concerns. Although culture cannot be said to necessarily conflict with civilization, there has always been a contrast between the two throughout history over which debates have been conducted. In time, the concepts solidified their connotations, and the contrast has become well-established.

These various treatments of culture contribute to its modern usage and complexity. Thinkers like von Humboldt used culture to describe material and concrete development and preferred civilization to describe moral and intangible development. Afterwards, the use of these words became clearer. Williams recognizes three broad categories of usage: "(a) the independent and abstract noun which describes a general process of intellectual, spiritual, and aesthetic development, from the $18^{\text {th }}$ century; (b) the independent noun, whether used generally or specifically, to indicate a particular way of life for a people, a period, a group, or humanity in general, from Herder and Klemm; and (c) The independent and abstract noun that describes the works and practices of intellectual, and especially artistic, activity. The third category, being relatively late, seems to lend itself to the widespread usage of culture to mean music, literature, painting and sculpture, and theater and cinema" (for a broader explanation, see Williams, 1985, pp.107-110).

Despite the diversity and wealth of meanings attributed to culture, one of these meanings stands out as quite handy in attempting to classify these meanings under specific titles: "Culture could refer to (1) refined artistic activities (classical ballet, opera); (2) all forms of life of a society or a group of people; or (3) shared systems and templates. These categories could also be identified as aesthetic, ethnographic, and symbolic cultural definitions, respectively." (Edles, 2006, pp. 5-6).

\section{Gökalp's Theory of Culture-Civilization}

Before addressing Gökalp's theory of culture and civilization and the meanings he attributes to these concepts, it would be useful to briefly examine the general research of Durkheim, who had an undeniably strong influence on Gökalp's sociological approach and terminology, without going into the details of his work, ideas, methodology, or concepts because the nation/state-based approach of Durkheim, which he offered as a solution to the problems of French society in particular, served as an exemplary model for Gökalp as he developed his proposals regarding the conditions of the Ottoman Empire's future survival and the sort of transformation the Empire would have to undergo in order to survive. 
Durkheim dealt with the problems encountered by modern industrial society, which had come into being from the mid- $18^{\text {th }}$ century onwards in Europe and was in the process of a rapid multi-dimensional institutionalization in the $19^{\text {th }}$ century, and the problems encountered by contemporary French society in particular. He was preoccupied with formulating the new principles of solidarity that were needed by modern society, which was a creation of the rapid economic, political, social and cultural transformations of the period, and that would match the new conditions. In other words, he tried to understand and analyze the problems accompanying the transition from a traditional society to a modern society; more importantly, he came up with proposals regarding the basic principles with which the modern industrial society of the future could or should solve its problems to survive. The central issues in his work were similar to those raised by the thinkers preceding him who had also worked on the problems of a modern society undergoing rapid transformation, as well as possible solutions to these problems, developing theories and making proposals to this end. He offered functional solutions in order to establish order on one hand, and to achieve progress on the other, which was not to be sacrificed for the sake of order.

Thus, Durkheim, aware of the dismantling qualities of modernity, was preoccupied with discovering mechanisms that would forge the tools and institutions out of this crisis, making it possible to establish a new order befitting these new conditions. He argued that solidarity in modern societies did not disappear, and that, on the contrary, the type of solidarity seen in traditional societies had become dysfunctional and new form of solidarity peculiar to modern society was taking shape (via his theory of social division of labor, and the distinction he made between mechanical and organic solidarity). In a sense, he proposed to solve social conflicts on the basis of social solidarity. In its solutions, he tried to develop a corporatist and solidarist model of society as opposed to liberalism's extreme individualism, conservatism's preference for the past over the present, or socialism's approach that could create a conflict out of class differences. His conceptualization of mechanical solidarity and organic solidarity, work on the sociology of religion, and inter-disciplinary approach should be interpreted as meaningful and functional parts of a comprehensive project for reaching these goals.

Following this very general summary of the main contours of Durkheim's work, I now return to Gökalp's project. At this point, it would be useful to briefly review the problems faced by the Ottoman Empire at the time Gökalp was writing his books and Turkish intellectuals' preoccupation with these problems.

First of all, just as Durkheim's sociology is a "sociology of the superstructure" (İlyasoğlu, 1985, p. 2170). Gökalp's priority is to provide the rulers of the Turkish state with an ideology and an identity, as well as to develop a new model of society. Thus, he mainly addresses the military and civilian bureaucracy. This seems to arise 
from the fact that he was officially and unofficially directly involved in politics; in other words, he was also a politician.

The Second Constitutional Period of the Ottoman Empire is important because it marked the first time a political party had come to power. With the proclamation of the Second Constitution, a period of intense press activity and an atmosphere of relatively free expression and discussion had been initiated. There was a rapid increase in both the number of newspapers and journals published and political parties formed until the Committee of the Union and Progress established total control over the administration. However, there was confusion in the minds of Ottoman intellectuals regarding political solutions. The political movements of Ottomanism, Islamism, and Turkism had each attracted large numbers of followers in succession within a short period of time, but none enjoyed consensus as the preferred solution. In other words, this period witnessed huge confusion at the level of ideas, as well as unrestrained and unguarded discussions of previous mentalities. In this context, shaping a new mentality that would keep the whole of society together in line with the new conditions of the era and the creation of a new ideology and new type of solidarity were seen as basic requirements. This, in essence, was the need Gökalp was trying to meet.

As Westernization became a state policy, criticism of the past increased both in volume and intensity. It became clear that under the new conditions, traditional identities and mentalities were no longer viewed positively, being seen as a relic of the past. The rapid loss of territory, and the massive internal and external crises the Empire faced, were seen by the statesmen, bureaucrats, and intellectuals of the era as vindication that traditional approaches were no longer practical. New proposals and ideologies were now being formulated and offered for solving social and political problems. All of these new solutions, including those based on tradition, accepted the premise that a new polity and a new model/understanding of society needed to be developed. In other words, it was widely accepted that even the traditional had to be reinterpreted if it were to serve as a solution or survive under the new conditions. What was expected from the nascent approach being developed was that it would provide for "progress," or Westernization, of society and state, but would do that without coming into direct conflict with its past identity because past culture/ identity had been becoming more important among the masses. At the same time, it lost its effectiveness, functionality, and significance as a political solution from the perspective of state elites. A cultural paradox would naturally mean a conflict between state and society.

Gökalp first tried to defuse this paradox by drawing a distinction between culture and civilization (hars and medeniyet). Using this distinction, Gökalp argued that it is possible for the Turkish nation to be integrated into Western civilization and 
simultaneously keep its own culture, as had happened in the past when Turks kept their culture but became the leading member and defender of the Islamic civilization. The conditions, however, had changed, according to Gökalp. It was now time for the Turkish nation to take its place within Western civilization, the shining star of modern times, but still preserve Turkish culture with its roots in Turkish history. This was possible because the two are separate things. Gökalp defined civilization on the basis of technology. In this sense, civilization is an asset that belongs to all of humanity.

As was previously argued, Gökalp made use of Durkheim's sociology, but successfully adapted it to Turkey's conditions. In addition, it should be mentioned that Gökalp was influenced by the ideas of many Western philosophers, psychologists, and social scientists (i.e., Worms, Bergson and Tarde) but had chosen to adapt Durkheim's sociological approach to the conditions of the Ottoman Empire, using his concepts and theoretical framework to offer solutions to the problems of Ottoman state and society. In other words, Gökalp's interest in Durkheim's ideas was not a reflection of blind admiration for everything Western, but the result of a conscious choice. Durkheim's concepts of order and morality correspond, in Gökalp's writing, to nation and progress. In Gökalp's work, Durkheim's collective consciousness became national consciousness. In some respects, Gökalp had an advantage over Durkheim because Islam still acted as an element of solidarity on societal order and state structures, even though the new intellectuals and the Republican administration that followed were hostile to the existing culture/identity, and by association, to Islam. Although the special emphasis put on religion by some groups did pose a threat, religion -the common culture centered on Islam- was still the major element of unity for a very large majority. Thus, Islam was important even in approaches that focused on the ideal and consciousness of the nation as the glue to hold society together. Gökalp was no exception to this: Islam was not his main reference; it was only one of the components of national feeling, national thinking, and national consciousness.

Gökalp was mainly concerned with producing theoretical solutions to the practical problems of the country. With this purpose, he used all scientific and philosophical tools at his disposal, which improved the scope and systematic structure of his ideas. “Gökalp's social and political doctrines were not simply analytical. They constituted a theory with strong normative elements based on social, political, and moral philosophy." (Parla, 1993, p. 55). Gökalp wanted to examine social and political facts, but he wanted to do that in a theoretical framework. His famous formulation "We are of the Turkish nation, of the Islamic Ummah, and of Western civilization" makes his theoretical framework very clear.

To Gökalp, Turkish nationalism represented a cultural ideal and philosophy of life that would provide the foundation for social unity and solidarity. It is not clear whether 
his nationalism was based on race or not. What he took from religion was unorthodox; he took moral, not political, elements that sprang from the more Sufi interpretations of religion that could be useful in creating social solidarity. In this respect, Gökalp was influenced by the "search for an earthly/secular order necessary to achieve social solidarity, unity, and integrity; and a secular-based morality as the foundation of this order," which was popular among post-Enlightenment European social scientists and a preoccupation of Durkheim's. In a sense, Gökalp, and thus Turkey, were fortunate compared to Western social scientists and European countries due to Turkey's unique circumstances, because Turkish intellectuals could make some use of Islam, especially its Sufi interpretation. As Parla (1993, p. 6) put it, "Turkism became the cultural norm, and Islam the moral norm, in Gökalp's societal model." In his usage, the concepts of westernization and modernization referred to the scientific, technological, and industrial achievements of European capitalism, and were the basis of his national reform program. His solidaristic-corporatist ideas, which sprang from corporatist capitalism developed in reaction to Marxism and liberalism, corresponded to a sort of idealist-positivist societal model. Gökalp called this model social idealism. In this model, the distinction between culture and civilization reinforces the belief in modernization, and a morality based on Islamic Sufism, especially the morality of duty, prevents the disintegration of society and individualization, even inspiring individuals to do everything in their power to contribute to the goal of modernization. Turkish nationalism has been used in terms of the spiritual tie that connects individuals to one another, reminding them that they belong to the same union.

Gökalp synthesized the trio of Turkism, Ottomanism, and Islamism -which were widely used in his time, especially following Akçura's (1904) influential essay that conceptualized the three as alternative/competing and mutually exclusive methods developed and implemented by Ottoman society for its salvation- in the form of Turkism/Islamism/Modernism, referring to Turkish nationalism, Islamic Sufism, and European corporatism. The theory and conceptualization of culture and civilization are better understood within this larger framework.

Before examining Gökalp's theory of culture and civilization in more detail, his attributing different meanings to these concepts at different times needs to be said, even if they are ultimately related. Sometimes he defined culture as the founding spirit of a nation that separates it from other nations on earth and civilization as the end point of its development; at other times, he defined culture as a national trait and civilization as an international consequence standing opposite culture, even though it carries cultural elements. Reading his texts, sometimes one gets the distinct feeling that his cultureversus-civilization dichotomy shares something with Durkheim's distinction between organic and mechanical solidarity, and with Tönnies' distinction between community 
and society. As Türkdoğan (1978, p. 11) observes, this pair of concepts permeates all of Gökalp's works, whether on education, history, art, politics, economy, culture, or literature. Naturally, the intellectual sources Gökalp drew upon when he developed the distinction between culture and civilization is a topic worthy of investigation.

According to Heyd (1950), Gökalp's distinction between culture and civilization is not found in Durkheim's work. Both Durkheim and Le Bon used the two concepts in the same sense, and they preferred the concept of 'civilization'. In other words, their "civilization" contains Gökalp's “culture" as well. Gökalp's theory of culture and civilization was an indirect adaptation from German sociology, maybe from Ferdinand Tönnies and his famous distinction between community (Gemeinschaft) and society (Gesellschaft). " "According to Tönnies, culture refers to tradition, religion and art; civilization refers to law and science. Just as societies develop out of communities, culture gives birth to civilization. Were these ideas, which represent Gökalp's views on culture and civilization, inspired by sociologists in Durkheim's circle who were influenced by Tönnies? We do not have documentary evidence regarding this issue. What we do know, however, is that the dichotomy Tönnies describes between culture and civilization is just as real for Gökalp.” (Türkdoğan, 1978, p. 23). Additionally, Türkdoğan (pp. 25-26) argues that Gökalp may have made use of European ethnographers' studies on the evolution of societies when he developed the distinction between culture and civilization, citing Findıkoğlu's (1966a, 1996b) argument that Gökalp may have been influenced by the work of German economists who had come to Turkey during the university reforms. ${ }^{5}$

4 "Gökalp seems to have borrowed his theory of culture and civilization indirectly from German sociology; perhaps from Ferdinand Tönnies who first published his famous Gemeinschaft und Gesellschaft in 1887. Among the many sociologists quoted in Gökalp's writings, Tönnies' name does not to occur. Tönnies' ideas are, however, known to have influenced French sociologists, whose works Gökalp studied, such as Gaston Richard, who at one period belonged to Durkheim's circle. In a critical review of Tönnies' book, Durkheim himself accepts the essential distinction between these two social forms with certain reservations.

Tönnies regarded culture as the expression of an organic society or community (Gemeinschaft) based on the 'natural will' (Wesenswille) of its members and reflects their emotional characteristics, while the 'free or abritrary will' (Kürwille, originally Wilkür), the product of the intellect to which it remains subject, creates the 'artifical' society (Gesellschaft) and its expression, civilization." (Heyd, 1950, pp. 66-67). Tönnies described congregation and community (Gemeinschaft and Gesellschaft) as follows: "I call any association dominated by natural demand congregation (Gemeinschaft), any of which is shaped by rational demands and directed by these is a community (Gesellschaft)," (Tönnies, 2000, p. 203). These definitions share similarities with some of Gökalp's ideas: "Evvelâ, hars millî olduğu halde, medeniyet beynelmileldir... Saniyen, medeniyet usul vasıtasiyle, irade ile yapılan şeylerin mecmuudur... Harsa dahil olan şeylerse, usul ile, fertlerin iradesi ile vücuda gelmemişler, sun'î değillerdir. Nebatların, hayvanların uzvî hayatı nasıl kendiliğinden ve tabiî bir surette inkişaf ediyorsa, harsa dahil olan şeylerin teşekkül ve tekâmülü de tıpkı öyledir. Meselâ, lisan fertler tarafından usulle yapılmış bir şey değildir... Demek ki harsın ilk numunesini lisanın kelimelerinde, medeniyetin ilk nümunesini de yeni lafizlar suretinde icat olunan 1stılâhlarında görüyoruz." (Gökalp, 1972, pp. 10-11).

5 "A university reform was carried out between the years 1914-1918, and a couple of German economists were hired. Gökalp, who used to be inspired by the French culture since 1906, thus came into contact with German economy and sociology. (...) It is highly probable that Gökalp developed the distinction between culture and civilization under the influence of this German sociology.” (Türkdoğan, 1978, p. 26). 
Berkes (1959, p. 317) observes that Gökalp's Türkleşmek, İslamlaşmak, Muasırlaşmak (1918) contains the chapter, "Hars Zümresi, Medeniyet Zümresi," [Culture Group, Civilization Group] originally published under the title "Community and Society" in the journal Türk Yurdu $(1913)^{6}$ supporting the arguments for German influence and Tönnies influence.

In his articles where he develops the theory of culture and civilization, Gökalp makes no open references that would allow researchers to track his intellectual sources within Western sociology or other academic disciplines. There is no evidence that Gökalp spoke German or directly followed German social sciences, ideas, or philosophy. However, considering the influence German intellectual developments and discussions had on intellectual circles within Europe, and the influence of German thinkers on names such as Durkheim, it is reasonable to assume that Gökalp had indirect knowledge of German intellectual traditions and discussions through French texts. In other words, the German intellectual influence on Gökalp was probably mediated by French texts produced by Durkheim and his disciples. German scholars hired within the framework of the university reform mentioned by Find1koğlu (1966a, 1996 b) probably also played an important role in the transmission of these ideas.

Gökalp defined culture and civilization as follows:

A society's "culture" refers to the totality of value judgments residing in the conscience of that society. Education is the process of turning this culture into its members' mental faculties. A society's "technology" refers to the totality of factual information residing in the mind of that society. Teaching is the process by which this information is turned into its members' mental habits. $\left(1981\right.$, p. 29) ${ }^{7}$

Gökalp viewed the value judgments and institutions appropriate for the collective consciousness of a society as living traditions. Traditions that are dead or no longer appropriate are called social fossils. Easily discernable, Gökalp approached the

6 This article, also reproduced in Berkes' edited book -which consists of translations of selected works of Gökalp- under the title "Community and Society", between pages 97 to 101, is more or less the same with the chapter titled "Hars Zümresi and Medeniyet Zümresi” in Türkleşmek, Íslamlaşmak, Muasırlaşmak with slight changes and substitution of the words culture and civilization instead of community and society. Similar topics Gökalp examined under different titles, and differences between the contents of pieces with the same title can shed light on some aspects of the development of Gökalp's thinking and should be investigated separately. In this context, there are significant differences between the way Gökalp uses the concept of 'culture' in his earlier work and its use in Türkçülüğ̈̈n Esaslarl, published later. For example, the word 'culture' is frequently used on its own in the earlier work, whereas in Türkçülügüü Esaslarl, it is often part of the phrase "national culture". His treatment of the words culture and civilization in another chapter titled "Culture and Refinement" in this book shows that he has somewhat softened the dichotomy between the two terms, possibly to adapt to the new circumstances.

7 Original Turkish: "Bir kavmin vicdanında yaşayan 'kıymet hükümlerinin mecmuuna o kavmin 'harsculture'1 denilir. Terbiye, bu hars1, o kavmin fertlerinde 'ruhi melekeler' haline getirmektir. Bir kavmin zihninde yaşayan 'şe'niyet hükümleri'nin mecmuuna o kavmin 'fenniyat-technologie'1 denilir. Talim, bu bilgileri o kavmin ruhi itiyatları haline getirmektir." 
issue from the perspective of selective/eclectic evolution. In other words, traditions currently observed in society are those that have been useful to society and thus have survived. That is, they have a function. The dead ones, on the other hand, need to be eliminated, which did not take place in Turkey. Rulers of the Tanzimat Era did not make any effort at elimination, which is why a duality emerged at the level of civilizations: Arabic-Persian Islamic civilization and European civilization. Later, ancient Turkish civilization was also added to this mixture. Gökalp was very much against this. One should remember that, consistent with these ideas, he was against adopting the Latin alphabet over the Arabic one currently used, and the extreme purification of the Turkish language. He valued the natural flow and continuity of the historical process. He was also against importing educational principles from Europe, emphasizing the need to give priority to national culture. ${ }^{8}$

Gökalp talked about two types of social groups and value groups, corresponding to the distinction between culture and civilization; moral duties, legal requirements, aesthetic values, ideals, and so on are subjective and specific to each cultural group. Scientific truths, economic principles, engineering, mathematical concepts, and the like, on the other hand, are objective, absolute, and belong to civilization groups.

Certain similarities can be detected between these ideas of Gökalp and Durkheim's concepts of mechanical solidarity and organic solidarity. It is also possible to find traces of Tönnies' distinction between community and society. Gökalp seems to argue that this distinction can be observed within the same society, that it is about two different dimensions of society: Culture, in this sense, provides solidarity based on similarities, whereas civilization allows solidarity based on differences. Within this framework, Gökalp developed arguments both for Turkish society specifically and for the world civilization to which he thinks Turkish society should belong as a member of international society. Turkey can be a part of modern civilization, preserving its culture and cultural values; it can both benefit from civilization and make contributions to civilization.

According to Gökalp, national culture should be able to provide a foundation for society based on social solidarity. Culture improves unity and solidarity, whereas international civilization may be detrimental for solidarity if affective factors underlying culture are confused with cognitive factors underlying civilization. Culture is a tie that connects the masses and elites in a society; however, if culture and civilization are not separated, if the boundaries between them are neither drawn appropriately nor followed, and if these two concepts, defined by Gökalp as belonging to different spheres, are interpreted as "competing cultures," civilization can become a divisive element.

8 Gökalp's seven articles on education are published in 1916 in Muallim Mecmuası. All of them can be found in Gökalp (1981). 
To support his thesis regarding the separation between culture and civilization, Gökalp attributed the collapse of the Ottoman state to the adoption of Arab-Persian values and institutions by Ottoman administrators instead of Turkish ones.

Gökalp observes that during the Tanzimat Era, new tensions were added to the already existing conflict between the Turkish culture widespread among the masses and the Ottoman (Arab-Persian) civilization dominant in palace circles: The tension within the elites between proponents of Arab-Persian civilization (ulema) and European-French civilization (pro-Western bureaucrats), and the tension between the masses and elites arose from the fact that Turkish culture opposes both. (Parla, 1993, p. 64)

Republican elites were anxious to create a secular Turkish nationalism, looking beyond the Ottoman-Islamic heritage; one of their favorite arguments to prove the point that Turks were second-class citizens in the Ottoman Empire and that they were persecuted and discriminated against was the claim that Ottoman elites referred to them as "thick-headed Turks" [etrâk-ı b̂-idrak]. ${ }^{9}$ Gökalp was among the first people to develop this discourse.

In the contrast between culture and civilization, Gökalp's sympathies lay with the former. He is of the opinion that some elements of European civilization can be selectively adopted, but civilization cannot be substituted for culture; on the contrary, the products of civilization can only be imported once they are adapted to the culture. What need to be imported are not values, but concepts and techniques. Moreover, the task of selecting belongs to the people, not the elites. Thus, public embracement is the main criterion. Gökalp complained about detached elites adopting moral and literary values in the name of civilization instead of technical competencies. In all of these arguments, his guiding principle was the creation of a sense of social unity and solidarity. According to Gökalp, when there is a big divide between the masses and the elites, and when this divide takes the form of culture versus civilization with one denoting the preferences of the masses and the other denoting the values of the elites, two separate nations are created.

9 Etrâk-ı b̂l-idrak was originally used by settled Turks to describe their nomadic brethren. It was probably a reflection of class differences. It is an expression used by urbanites to emphasize nomads' lack of civility and manners, and a reflection of different rules of etiquette observed in different communities. Reaching the conclusion that the Ottoman dynasty saw Turks as second-class citizens solely on the basis of such evidence is a far-fetched interpretation, to say the least, and a product of the efforts to construct a new nationalism by otherizing the Ottoman past (One should remember that this was a common tactic many countries carved out of the Ottoman Empire used to form their nations, in particular Balkan and Arab nations). Nevertheless, Gökalp's distinction between culture and civilization, as previously mentioned, was first and foremost an expression of the idea that abandoning a previously inhabited world is not a matter of essence: just as the Western civilization which Turks were about to enter was external, so was the circle of civilization they were about to leave. Gökalp was careful to emphasize this difference in all matters relating to Turkish nationalism. To this end, he didn't miss the opportunity to exploit etrâk-ı bî-idrak. 
As he developed the abstract dichotomy between civilization as utilitarian, selfish, and interest-based, and culture as non-utilitarian, selfless, public-minded, and idealist, Gökalp made use of concrete models of society: the solidarist model (seen in Turkish and Islamic societies and some Western societies) as opposed to the liberal (Western) model of society. Then he made a connection between the collapse of cultures and the spread of imperialist states. He viewed imperialism as ultimately a product of liberal capitalism. To Gökalp, modernization and European civilization meant the industrial and technological achievements of capitalism, and the positive sciences that made them possible, nothing more.

In Türkçülüğün Esaslarl ([The Principles of Turkism]; 1923), he repeated some of his previous views on the relationship between culture and civilization, as well as between nationalism and internationalism. However, this book, penned after the proclamation of the Republic in 1923, placed less emphasis on culture and nationalism against internationalism and civilization, not more. Gökalp had already made the distinction between national culture and international civilization and strove to bridge the divide in this new period. In this book, Gökalp argued that the 'social life' of a society consists of its religious, moral, linguistic, political-legal, economic, philosophical, and scientific lives. The last two items on this list had been classified as belonging to civilization in Gökalp's previous work and could only become a part of national culture if and the degree to which they were adapted to the culture of the people and embraced by them.

In the chapter "Hars ve Tehzib" [Culture and Refinement] in Türkçülüğün Esaslarl (1923), Gökalp tried to bring culture and civilization even closer. He argued that culture refers to folk culture, that it is democratic, and that it consists of a people's traditions, habits, customs, literature in its written and oral forms, language, music, religion, moral and aesthetic values, and economic products. Refinement, on the other hand, corresponds to high culture. It is aristocratic and peculiar to highly educated intellectuals. However, because both folk culture and high culture spring from the same national culture, the difference between them is not a qualitative one but a matter of degree. Thus, intellectuals with high culture are not cosmopolitans, but national elites.

This change in Gökalp's thinking reflects the transformation the country was undergoing at the time. With the war finally over, certain characteristics of the new state and the charisma or trust enjoyed by the founding cadre influenced Gökalp's thinking. Gökalp also had an explanation for this new situation.

Gökalp's understanding of Turkish nationalism was clearly and definitely based on linguistic and cultural nationalism. He wanted to co-exist in peace and mutual respect with other nations. "Turanism, the racist and irredentist brand of Turkish 
nationalism, does not figure even as an ideal in any of his theoretical or political articles and essays in [that] period," (Parla, 1993, p. 73). Türkçülüğün Esasları also happens to be the book that provides a systematic presentation of Gökalp's views on nationalism. The book focuses on the system and program of Turkism. The history of Gökalp's views on nationalism can be traced back to Türkleşmek, Islamlaşmak, Muasırlaşmak, a collection of his articles written at different times. Articles directly on the subject are "Türklügüü Başına Gelenler," "Türk Milleti ve Turan", and "Milliyet Mefkûresi" [Arriving at the Head of Turkism, The Turkish Nation and Turan, and The Ideal of the Nation, respectively]. These articles also reflect the social function Gökalp attributed to nationalism, or the ideal of the nation. In Türkçlügün Esaslarl, on the other hand, this ideal was not as clearly expressed because Gökalp thought that the ideal of nationalism had already achieved its purpose. When he wrote that Turks lack a sense of national responsibility, national consciousness, and national ideals, that they are a collection of completely fragmented and separated individuals, and that their lack of progress is due to a "failure to know oneself" and "failure to grasp national responsibility", he is in fact calling attention to the social function of nationalism as a normative system providing solidarity. What mattered to Gökalp was social solidarity, and nationalism is justified by the need for solidarity.

Gökalp did not pay attention to the political, legal, or theological aspects of Islam; he did not want religion to be a determinant of social life, especially at the level of politics. He argued that politics should be cleansed of any traces of theocracy, and legislative power should be solely in the hands of the state. He was interested in Islam as an element of solidarity for Ottoman-Turkish society. His views on the modernization of religion aimed to rid Islam of its legal and political rules and turn it into just a system of morality. In addition, these views are reminiscent of Durkheim's identification of God and society.

For Gökalp, what is important about Islam is its Sufi interpretation. He compared Sufi leaders to the idealist philosophers of Europe. In line with the positivist-idealist corporatist system he was trying to build, Gökalp borrowed idealist elements from the Sufi understanding of morality for he believed Sufism is the antidote to selfish individualism, considered to be the destructive element of liberalism:

Mainly, he sought to demonstrate the essential affinity of a secular moral philosophy and scientific social theory to Sufi philosophy and ethics. Islam thus constituted only one part of his general ethical system in support of cultural Turkism and moral solidarism. (Parla, 1993, p. 85). 


\section{A Critical Evaluation of the Theory of Culture and Civilization}

In Gökalp's conceptualization, culture -national culture in particular- is the beginning of the road that passes through a national state and leads to civilization. ${ }^{10}$ In addition, the culture-civilization approach was understood and interpreted as the theoretical explanation of how the Turkish nation could progress or westernize while keeping its own identity. Gökalp's synthesis of Turkism-Islamism-Modernism is clearly part of an effort to create a new, uniting, and arousing spirit. Similarly, it is true that the theory of culture and civilization is part of the effort to provide an answer to the question "How can we achieve progress?" However, both approaches are based on some paradoxical foundations, and these paradoxical foundations create many areas of potential conflict. These approaches, notwithstanding their unifying, peaceful, solidifying, and cooperative goals combined with certain practices of the Republican era, led to serious conflicts, a point commonly overlooked.

One should always keep in mind that Gökalp's priority was to create a new identity and a new ideology for the future Turkish state and society, to create a new nation. ${ }^{11}$ The theory of culture and civilization had an important role to play in reaching this goal. ${ }^{12}$ If the goal is to create a new ideology, a new identity, and ultimately a new nation, criticism of the current situation naturally becomes a priority. This is why the theory of culture and civilization has a dual function: First, Gökalp wanted to justify or provide justification for the idea of abandoning the currently inhabited circle of civilization with this theory; second, the moment this separation was commonly accepted as justified or necessary, he provided a justification for the policy of integrating with the targeted world.

I argue that the theory of culture and civilization is first and foremost an attempt to provide justification for "abandoning the old circle of civilization" before being

10 "Millî kültür ile medeniyet arasındaki bir münasebet de şudur: Her kavmin, ilk önce, yalnız millî kültürü vardır. Bir kavim, kültür bakımından yükseldikçe siyasetçe de yükselerek kuvvetli bir devlet vücuda getirir. Diğer taraftan da, kültürün yükselmesinden medeniyet doğmağa başlar.” (Gökalp, 1990, p. 42).

11 "Dünyanın Doğusu da, batısı da bize açık bir biçimde gösteriyor ki, bu çağ, milliyet çağıdır; bu çağın vicdanları üzerinde en etkili güç milliyet ideâlidir. Toplumsal vicdanların yönetimi ile sorumlu olan bir Devlet, bu önemli toplumsal etmeni yok sayarsa görvini yapamaz. Devlet adamlarında, parti ileri gelenlerinde bu duygu bulunmuyorsa, Osmanlılığı meydana getiren dinî topluluklar ve çeşitli kavimleri ruhî bir biçimde yönetmek olanaklı değildir. Dört senelik bir deneme bize [şunu] gösterdi: Yalnızca unsurların birbirine kaynaşmaları amacıyla 'Ben Türk değilim, Osmanlıyım' diyen Türkler, unsurların ne tür bir uzlaşmaya evet diyebileceklerini sonunda çok acı bir biçimde anladılar. Milliyet duygusunun egemen olduğu bir ülkeyi ancak, milliyet zevkini benliklerinde duyanlar yönetebilirler.” (Gökalp, 1996: 13).

“İçtimaî işbölümünün tesiriyle, cemiyetler demokratlaşmağa başlayınca, imparatorluklar inhilâle yüz tuttu. Asrî devlet, millet ve halka kıymet verdiği için, halkın vicdanında hala yaşamakta olan harsî müesseseler yeniden kıymet bulmağa başladı. Yani, millî harslar, eski zaman defineleri gibi, milletin a'makında gömülü bir halde iken, keşf olunarak meydana çıkarıldılar." (Gökalp, 1972: 32) (first edition: Yeni Mecmua, September 12, 1918, p. 61).

12 Nihat Nirun underlines the importance of the concept of "culture" in Gökalp's general theory as follows: "Ziya Gökalp's sociological system is based on three important concepts. At the foundation of the system is CUSTOM and everything it implies, its body is CULTURE, and its roof is IDEAL.” (Nirun, 1999: 1). 
an answer to the question of "How can we progress?" or "How can we westernize?" If all the problems the Ottoman state faces are attributed to the traditional structure/ identity that failed to produce adequate responses to new conditions, and if the ultimate solution to all problems is identified as entering a new circle of civilization and this is adapted as a policy, naturally one first has to effect separation from the currently inhabited circle of civilization. Gökalp chose to justify abandoning the traditional identity by making use of the sociological concepts and theories developed by Western sociology and by building two categorical spheres in direct opposition to one another, culture and civilization. The opposition between culture and civilization, thanks to the ingenious tactics and strategies used by Gökalp, was presented as being between masses and elites, between rural and urban, or between natural and artificial, without falling into the trap of being anti-religious or anti-Islamic. This approach, although perfect on paper, yet contained some misunderstandings and misinterpretations and thus had the potential to do great damage in practice. The way people, who are seen as the ultimate criterion for everything, actually defined themselves was in discord with Gökalp and his followers' idea of Turkism. This fact was only discovered when they came to interact with or, more properly, attempted to transform the people. When they tried to turn their ideas into reality, when they set about to teach people just what Turkism, which masses were supposed to adopt and internalize, was, they were unable to avoid being positioned as anti-Islamic because the Ottoman people saw the Arab-Persian civilization, who Gökalp had reduced to a category with no organic connection to the people -a creation of elites and rulers alienated from their own society- as an indispensable part and constituent element of their culture, contrary to Gökalp. Among the people, being Turkish was equated with being Muslim, both in theory and in practice. As a result, masses were not willing to cleanse the elements that Gökalp had defined as artificial from their culture; they saw coercive attempts to this end as violent attacks on their very existence, essence, and religion and developed active resistance against such policies.

Implementing the theory in practice or testing the theory in the real world requires questioning some of its claims. Gökalp's call to understand people, whom he viewed as the main source of Turkish culture, or national culture, and his call to "go to people" to unearth this culture need to be questioned within this framework. In other words, one needs to test to what degree this claim fits with his argument that culture is natural and arises by itself.

Gökalp was of the opinion that there is no room for conscious intervention in culture. However, implementing Gökalp's ideas in practice leaves one face-to-face with nothing but a top-down, sometimes coercive, conscious intervention. Going to the people necessarily implies that there is a distance between those going and the people. In practice, this distance is not simply a matter of horizontal distance either. 
It is also, and more often not, a vertical distance. Those at the top go to those at the bottom. Those at the top are the distinguished, and the enlightened go to those in need of enlightenment. The fact that those at the top love those at the bottom and/or that the former are compassionate towards the latter does not change the basic fact that this is a hierarchical relationship. Ultimately, if a cultural effort were to be undertaken, the decision naturally laid with those at the top. Those going to the people were to "pick and choose" as they unearthed what the people had. In other words, when they saw that there was a disconnect with what they had imagined to be the people's values and what values the people actually held, Gökalp would declare that these people were Turkish but unaware of their Turkishness, and the task of unearthing what the people had would turn into teaching people what being Turkish means and how to be Turkish; in other words, enlightening people.

Second, Gökalp seemed to be aware that there was more than one Europe. However, instead of treating the different Europes separately, he chose to undertake a much more difficult project and discussed these differences by way of dividing Europe into its component parts: culture and civilization, ethics and science, and values and technology. This artificial separation resulted in many ambiguities that needed explaining in Gökalp's theory. Contemporary European civilization cannot be imagined separately or independently from the scientific, philosophical, artistic, literary, cultural, economic, social, and political developments in modern history, from the nations that make up Europe, or from these nations' cultural values. In other words, modernity in all its dimensions is the foundational outlook that has shaped and constituted the contemporary European civilization and its nations. It is very difficult if not impossible to separate these highly integrated elements. One should keep in mind that when Durkheim studied the French nation, he was studying the values of modernity. The same goes for Marx and German philosophers. As Parla argued:

For Gökalp, modernism, or Westernism, or European civilization, meant the industrial and technological achievements of capitalism and positive sciences... In Türkçülü̈̆̈̈n Esasları (1923), Gökalp regenerated these views on the relationship between culture and civilization, and between nationalism and internationalism. However, it should be noted in this last work, which appeared after the realization of the ideal of nationalism and the formation of the Republic in 1923, that his emphasis on culture and nationalism, as contrasted with internationalism and civilization, was not accentuated but toned down. (1993, pp. 68-69) $)^{13}$

Gökalp was justified only up to a point when he made the following argument:

Institutions that connect all the members of a society to one another and generate solidarity are "cultural institutions," and "culture" is the name given to the totality of these institutions.

13 To see the change and the softening in question, the chapters "Milli Kültür ve Medeniyet" and "Hars ve Tehzib" should be consulted. 
Institutions that connect the upper classes of a society to the upper classes of other societies, on the other hand, are "institutions of civilization," and the totality of these institutions, all of which are of the same kind, is called "civilization." $\left(1972\right.$, p. 1) ${ }^{14}$

Later, he would try to bring the two closer, as evident in his chapter "Hars ve Tehzib". ${ }^{15}$

A third point is that Gökalp's work on the relationship between culture and civilization indicated a permanent tension between the national culture (Turkish nation/state) and the European civilization. This tension-ridden relationship, which characterizes Turkish modernization in general, combines admiration and fear of Europe ${ }^{16}$ Europe is a model to be followed if the country is to progress, but it is also an imperial entity that threatens to assimilate. This dilemma and tension are clearly visible in the following passages from Gökalp:

The Ottoman culture started to be influenced by another civilization from the Tanzimat Era onwards. Just as it had abandoned the Chinese civilization and adopted the Persian civilization in the past, now it was abandoning the Persian civilization and adopting the European civilization. (1972, pp. 4-5) $)^{17}$

Our national music used to compete with Persian tastes in the past, now we also have to compete with French tastes..." (p. 5) ${ }^{18}$

Since civilization consists of institutions shared between nations, the only essential elements of civilization are positive science and industrial technology. Because European civilization has attained perfection in these two respects, adopting European civilization is a precondition for our progress. By borrowing these two treasures of power from Europe, we will achieve great progress... Apart from that, the European civilization will also have positive effects on our aesthetic and moral values. They are positive as much as they help destruct the philosophical, moral, and aesthetic values imported from Persia. The moment they attempt to substitute the values destructed, they turn negative. The aesthetic, moral, and philosophical values of a nation are unique unto itself. They cannot be imported from the outside. What can

14 Original Turkish: "Bir cemiyetin bütün fertlerini birbirine bağlayan, yani aralarında tesanüd meydana getiren müesseseler 'harsî müesseseler' dir. Bu müesseselerin mecmuu, o cemiyetin harsını teşkil eder. Bir cemiyetin üst tabakasını başka cemiyetlerin üst tabakalarına rapteden müesseseler de 'medenî müesseseler'dir. Bir neviden olan bu gibi müesseselerin yekûnu 'medeniyet' namını verdiğimiz mecmuayı meydana getirir." (article originally published in Yeni Местиа, September 5, 1918, p. 60).

15 At this point, it should be remembered that by the end of 1930s, Gökalp's distinction between culture and civilization was found to be unrealistic by Republican elites, and criticized as one of the reasons for the failure of Westernization efforts, leading to a new policy of total Westernization that did not separate morality from technology, and a monumental project known as the "translation of classics" was initiated within this framework. For a criticism of past efforts at Westernization, including Gökalp's based on the distinction between culture and civilization, published on the centennial of the Tanzimat Edict, see Ülken (1940). For more on this effort of total Westernization, also called Turkish humanism, see Sinanoğlu (1988). On the translation of classics, see Bulut (2008).

16 For an evaluation of Turkish modernizers' tension-ridden psychologies and practices, see (Ahıska, 2010).

17 Original Turkish: "Osmanlı harsı, Tanzimat devrinde yeniden başka bir medeniyetin nüfuz sahasına girmeğe başladı. Vaktiyle Çin medeniyetinden kurtulup İran medeniyetine girdiği gibi, şimdi de İran medeniyetinden kurtularak Avrupa medeniyetine giriyordu."

18 "Millî musikimizin rakibi, evvelce yalnız İran zevki iken, şimdi bir de ona Fransız zevki inzimam etti." 
be imported are concepts, methods, and technologies. Feelings, emotions, and tastes, because they are elements of culture, have to be completely national. (pp. 5-6) ${ }^{19}$

A sense of aesthetics should be received from people, the most national element in our nation, not from foreigners... In law, ethics, philosophy, and economics, methods and systems should be European but the spirit should be national and in accord with the people and their way of life. (pp. 8-9) ${ }^{20}$

Culture constitutes the faculty of conscience, which is tasked with evaluating and classifying normative concepts (values), whereas civilization constitutes the faculty of intellect, which is tasked with investigating and composing empirical concepts (facts)... One (culture, conscience) responds to our question of "What to live for?" with the answer "For ideals." The other (intellect, civilization), responds to our question of "How to live?" with the answer "Reasonably." One supervises our will through normative judgments; the other supervises our prudence through empirical judgments. In sum, one provides us with the ends; the other provides us with the means. (pp. 36-39) $)^{21}$

Gökalp uses the dual concepts of culture and civilization at two different levels and describes different types of relationships between the two at different levels. The first level is when he uses the concepts for a closed and isolated society. At this level, culture is understood and interpreted as the founding spirit of this society. At the second level, an open society interacting with the world seems to have been imagined. In other words, each society was imagined as a self-contained entity at the first level, and as part of a single-world society at the second level. Out of these open and interacting societies, a world of nations developed following a linear line. This approach reflects a European-centered understanding of history. Societies, each with a founding essence making them distinct from others, are assumed to have to enter the most developed circle of civilization because civilization shows how this founding spirit can materialize and survive in a concrete form (shapes its outward appearance). This is exactly the source of Gökalp's troubles. What is the nature of the relationship

19 "Medeniyet milletler arasında müşterek müesseseler olduğuna göre, medeniyetin hakikî unsurları müsbet ilimlerle sınaî fenniyelerdir. Avrupa medeniyeti, bu iki hususta kemal mertebesini iktisap ettiği için, Avrupa medeniyetine girmek milletimize bir tealî mebdei hükmündedir. Avrupa'dan bu iki kudret hazinesini almakla, biz büyük terakkilere nail olacağız. (...) Bundan başka, Avrupa medeniyetinin bediî ve ahlakî zevkler itibariyle de üzerimizde hayırlı tesirleri olacaktır. Fakat, bu tesirler münhasıran, bize Acem'den intikal etmiş olan felsefî, ahlakî ve bediî zevkleri yıkmağa çalıştığı müddetçe faydalıdır. Yıktığı zevkin yerine kaim olmağa yeltendiği anda, bu iki medeniyet zevki muzır olur. Bir milletin bedî̂, ahlakî, felsefî zevkleri kendine mahsustur. Bunları aslâ hariçten alamaz. Hariçten yalnız mefhumlar, usuller, fenniyeler istiare edebilir. Duygular, heyecanlar, zevkler, harsın unsurları olduğu için tamamiyle millîdir."

20 “Zevkî terbiyeyi, yabancılardan değil, milletimizden ve milletimiz içinde en çok millî kalan halkımızdan almağa çalışmalıdırlar. (...) Hukuk, ahlak, felsefe ve iktisatta da usuller ve sistemler Avrupaî olmalı, fakat ruh tammiyle halka, hayata uygun ve millî bulunmalıdır."

21 Original Turkish: "Hars hadiseleri fertte "inşaî mefhumları yani kıymetleri takdir ve tasnif hizmetile mükellef olan' vicdan melekesini, medeniyet hadiseleri ise 'ihbar mefhumları, yani hakikatleri tahkik ve terkip işine memur olan' akıl melekesini husule getirmiştir. (...) Birincisi (hars, vicdan) bizim niçin yaşamalı? sualimize mefkûre için cevabını verir. İkincisi (akıl, medeniyet) nasıl yaşamalı sualimize 'makul bir surette' diye mukabele eder. Birincisi inşaî hükümlerle irademizi, ikincisi ihbarî hükümlerle müdebbiremizi sevk ve idare eder. Hülâsa birincisi bize gayeleri, ikincisi vasıtaları gösterir.” 
between essence and appearance? How can one assume a temporary appearance while still keeping one's essence? Wouldn't assuming another appearance do damage to the essence described as "peculiar to us"? Gökalp is very sensitive on this point and keeps returning to the relationship and boundary between culture and civilization. On this point, he makes different and sometimes apparently contradictory arguments. He sometimes describes culture and civilization in opposition to one another, and at other times describes civilization as a more advanced and abstract version of culture, with organic ties between them. In yet another formulation, unearthed national culture contains some elements of Western civilization.

\section{Conclusion}

Gökalp sometimes uses the distinction between culture and civilization in a way that is reminiscent of the community-society distinction. Sometimes it reminds the reader of Durkheim's mechanical solidarity and organic solidarity... Sometimes it contains the urban-versus-rural dichotomy. At other times, it carries asabiyyahrelated connotations pointing to Ibn Khaldun's distinction between Bedouins and townspeople. Most of the time, however, his comments and justifications are based on the distinction between plebs and patricians, upper classes and lower classes. This effort ultimately culminates in the opposition between national and international.

Culture is sometimes described as a founding spirit. However, when the focus is on making a distinction, culture as a system of references is never mentioned. In this sense, the issue of dualities is taken up in a very haphazard and unrealistic manner, exploited in service of policies already chosen for implementation. ${ }^{22}$

Gökalp's general theory of society claims to provide a new, nation-based, and solidarist identity and ideology for the Ottoman state and society. Similarly, his culture-civilization theory aims to provide a legitimate explanation of how new society can achieve harmonious progress. However, in his efforts to develop a theory to create urgent solutions to the problems of the Ottoman Empire, Gökalp seemed to have overlooked the depth and multi-dimensionality of European thought, in addition to the real dynamics of Ottoman society. Faced with urgent political problems and the intellectual pressures of his time, and torn between ideals and reality, he was compelled to resort to an eclectic approach. Although his reasons are understandable,

22 For example: "Niçin Türk enmuzecinin her şeyi güzel, Osmanlı enmuzecinin her şeyi çirkindir? Çünkü Osmanlı enmuzeci Türk'ün harsına ve hayatına muzır olan emperyalizm sahasına atıldı, kozmopolit oldu, sınıf menfaatini millî menfaatin fevkinde gördü. Filhakika Osmanlı İmparatorluğu genişledikçe, yüzlerce milletleri siyasî dairesine aldıkça, idare edenlerle idare olunanlar ayrı iki sınıf haline giriyorlardı. İdare eden bütün kozmopolitler Osmanlı sınıfını, idare olunan Türkler de Türk sınıfını teşkil ediyorlardı. Bu iki sınıf, birbirini sevmezdi. Osmanlı sınıfı, kendini millet-i hakime suretinde görür, idare ettiği Türklere millet-i mahkûme nazariyle bakardı. Osmanlı daima Türk’e eşek Türk derdi. Türk köylerinde resmî bir şahıs geldiği zaman, Osmanlı geliyor diye herkes kaçardı. Türkler arasındaki Kızılbaşlığın ruhu böyle bir ayrılıkla izah olunabilir." (Gökalp, 1972, p. 17). 
the fact that his theories contain serious paradoxes that would surface when put into practice is undeniable.

Do the eclecticism and the paradoxes spring from a permanent quality, or are they results of a temporary strategy adopted out of necessity? Of course it is not possible to answer this question with any amount of certainty. A chronological reading may unearth certain fluctuations in his assessments of the future of the Ottoman state and Turkish society, but the ultimate goals of Gökalp's theory remain constant. Gökalp developed an open-ended theory from the outset, and each new development saw Gökalp not changing his goals but adapting and reinterpreting his theory in line with the new conditions, all while making his goals more explicit.

Starting with his early articles on the principles of Islamic jurisprudence, Gökalp called attention to the gulf between life and doctrine and prioritized the flow of life. This basic approach shows that, despite his obscure style of writing and in light of his later work, Gökalp had a definite and clear vision for the future of Turkish society and had started to express his ideas more clearly over time as conditions became more favorable.

\section{References}

Adorno, T., \& Horkheimer, M. (2011). Sosyolojik açılımlar: Sunular ve tartışmalar [Sociological expansions: Presentations and discussions] (M. S. Durgun \& A. Gümüş, Trans.). Ankara, Turkey: BilgeSu.

Ahıska, M. (2005). Radyonun sihirli kapısl: Garbiyatçılık ve politik öznellik. Istanbul, Turkey: Metis Yayınları.

Ahıska, M. (2010). Occidentalism in Turkey: Questions of modernity and national identity in Turkish radio broadcasting. London \& New York: I. B. Tauris Publishers.

Akçura, Y. (1976). Üç Tarz-ı Siyaset [Three styles of politics], Ankara, Turkey: Türk Tarih Kurumu Yayınlar1 (first edition, as an article, in Turk Gazetesi, 1904, pp. 24-34, Cairo (Egypt); second edition, 1912 (1327), Istanbul, Turkey: Kader Matbaas1).

Berkes, N. (1959). Turkish nationalism and western civilization. New York, NY: Columbia University Press.

Bulut, Y. (2008). Hasan Ali Yücel: İcraatları ve eserleriyle bir eğitim bakanının portresi [Hasan Ali Yücel: Portraits of a minister of education through his performance and works]. Türkiye Araştırmaları Literatür Dergisi, 6(12), 665-684.

Edles, L. D. (2006). Uygulamalı kültürel sosyoloji [Applied cultural sociology] (C. Atay, Trans.). Istanbul, Turkey: Babil Yayınlar1.

Elias, N. (2000). Uygarlık süreci: Cilt I [The civilizing process: Vol. I] (E. Ateşman, Trans.). Istanbul, Turkey: İletişim Yayınları.

Elias, N. (2002). Uygarlık süreci: Cilt II [The civilizing process: Vol. II] (E. Özbek, Trans.). Istanbul, Turkey: İletişim Yayınları.

Fındıkoğlu, Z. F. (1966a). Sosyalistler XIII - Ziya Gökalp, [The socialists, XIII, Ziya Gökalp]. Istanbul, Turkey: Türkiye Harsî ve İctimaî Araştırmalar Derneği Yay. 
Fındıkoğlu, Z. F. (1966b). Ziya Gökalp Sosyalist midir? [Is Ziya Gökalp a socialist?]. İş ve Düşünce Dergisi, 254, 17-45.

Gökalp, Z. (1972). Hars ve medeniyet [Culture and civilization] (2nd ed.). Ankara, Turkey: Diyarbakır'ı Tanıtma ve Turizm Derneği.

Gökalp, Z. (1981). Makaleler V [Essays, vol. V] (R. Kardaş, Ed.). Ankara, Turkey: TC Kültür Bakanlığı Yayınları.

Gökalp, Z. (1990). Türkçülüğün esasları [The principles of Turkish nationalism] (M. Kaplan, Ed.). Istanbul, Turkey: MEB Yayınları.

Gökalp, Z. (1996). Türkleşmek, İslamlaşmak, muasırlaşmak [Turkification, Islamization, Modernization]. Istanbul, Turkey: Kamer Yayınları.

Heyd, U. (1950). Foundations of Turkish nationalism: The life and teachings of Ziya Gökalp. London, UK: Harvill Press Ltd.

İlyasoğlu, A. (1985). Türkiye'de sosyolojinin gelişmesi ve sosyoloji araştırmaları [Development of sociology and sociological researches in Turkey]. In Cumhuriyet'ten Günümüze Türkiye Ansiklopedisi (pp. 2164-2174). Istanbul, Turkey: İletişim.

Kroeber, A. L., \& Kluckhohn, C. (1963/1952). Culture: A critical review of concepts and definitions. New York, NY: Vintage Books.

Nirun, N. (1990). Sistematik sosyoloji açısından Ziya Gökalp [Ziya Gökalp from the perspective of systematic sociology]. Ankara, Turkey: TC Kültür Bakanlığı Yayınları.

Parla, T. (1993). Ziya Gökalp, Kemalizm ve Türkiye'de korporatizm [Ziya Gökalp, Kemalism, and Corporatism in Turkey] (F. Üstel \& S. Yücesoy, Eds.; 2nd ed.). Istanbul, Turkey: İletişim Yayınları.

Sinanoğlu, S. (1988). Türk hümanizmi [Turkish humanism]. Ankara, Turkey: Türk Tarih Kurumu Yayınları.

Thomas, H. (2012). Kültür/Doğa [Culture/The East]. In C. Jenks (Ed.) \& İ. Çapçığlu (Trans.), Temel Sosyolojik Dikotomiler (pp. 159-177). Ankara, Turkey: Birleşik Yayınevi.

Thompson, J. B. (2013). Ídeoloji ve modern kültür: Kitle iletişimi çağında eleştirel toplum kuramı [Ideology and modern culture: Critical social theory in the age of mass communication] (I. Çetin, Trans.). Ankara, Turkey: Dipnot Yayınları.

Tönnies, F. (1944). Cemaat ve cemiyet nazariyesi [The Theory of Community and Society] (Z. F. Findıkoğlu, Trans.). İ̈ Hukuk Fakültesi Mecmuası, 9(3-4), 712-748.

Tönnies, F. (2000). Gemeinschaft-Gesellschaft [Community-Society], In A. Aydoğan (Trans.), Şehir ve Toplum: Weber, Tönnies, Simmel. Istanbul, Turkey: İz Yayınc1lık.

Türkdoğan, O. (1978). Ziya Gökalp Sosyolojisinde Bazı Kavramların Değerlendirilmesi [Evaluating some concepts in the sociology of Ziya Gökalp] (3rd ed.). Istanbul, Turkey: Türk Kültür Yayını.

Tylor, E. B. (1871). Primitive Culture: Researches into the Development of Mythology, Philosophy, Religion, Art and Custom. 2 vols. London, UK: John Murray.

Tylor, E. B. (1919/1881). Anthropology: An introduction to the study of man and civilization. New York, NY: D. Appleton \& Co.

Ülken, H. Z. (1940). Tanzimattan sonra fikir hareketleri [Idea movements after the Tanzimat]. In Tanzimatın 100. Yllı Sempozyumu (pp. 757-775). Istanbul, Turkey: Maarif Vekaleti.

Williams, R. (1985). Keywords: A vocabulary of culture and society (2nd. ed.). New York, NY: Oxford University Press. 